\title{
A persistent population of the chocolate-band snail Eobania vermicu- lata (Gastropoda: Helicidae) in Belgium
}

\author{
Jelle Ronsmans ${ }^{1, *} \&$ Tom Van den Neucker ${ }^{2}$
}

\author{
Royal Belgian Society for Conchology, Rerum Novarumlaan 26, 2300 Turnhout, Belgium. \\ 2 University of Antwerp, Department of Biology, Ecosystem Management Research Group, Universiteitsplein 1C, B-2160 \\ Wilrijk, Belgium. \\ *Corresponding author: jelle_ronsmans@msn.com
}

KEY WORDS: Mollusca, Eobania vermiculata, alien species, non-native species, Belgium

Eobania vermiculata (O.F. MüLLER, 1774) is a large land snail species, with a maximum shell width of $33 \mathrm{~mm}$. The species occurs in a variety of habitats, usually in dry vegetation, in hedgerows, gardens, vineyards and agricultural fields, often in coastal areas. Reproduction takes place in autumn. About 60 to 80 eggs are laid in the soil. The snails reach maturity two years after hatching. Adult snails hibernate in a hole in the soil and develop an epiphragma. Juveniles usually hibernate under stones or leaves [1,2]. Eobania vermiculata is a circum-Mediterranean species. Its native range extends from Spain to Turkey in Europe and along the North-African coast at least from Morocco to Libya, although it is absent as a native species in the SE of the Mediterranean region. The species has been introduced into several European countries, including Germany, Hungary, and The Netherlands. Introduced populations also occur in the USA, Australia, Japan, South Africa, Egypt, Israel, Saudi Arabia, Jordan, and Iran [1-9].

On September $17^{\text {th }} 2014$ five empty shells of E. vermiculata were collected near the Zeebrugge harbour (51 $\left.20^{\prime} 16^{\prime} \mathrm{N} ; 3^{\circ} 10^{\prime} 47^{\prime} \mathrm{E}\right)$ in Belgium. The locality at Zeebrugge is a steep, SE-facing sandy slope situated between a road and a railroad track used for container traffic. Vegetation consisted of short grasses (mainly Elytrigia atherica), herbs and young Rubus caesius. During an additional half hour search carried out by two persons on November $9^{\text {th }} 2014$ twenty living juvenile and adult E. vermiculata and >
40 empty shells were found at the same locality. Most living E. vermiculata were found amongst rubble, mainly wooden planks and plastic, and in drainage pipes. Approximately one year after the species was first recorded, on September $9^{\text {th }}$ 2015, a follow-up survey was carried out during a conchological excursion with a group of twelve persons. A 15-minute search yielded a total of 144 live E. vermiculata including 15 juveniles, and 22 empty shells. Finally, on September $10^{\text {th }}$, an extra 409 adult individuals, 49 juveniles, and 45 empty shells were found by two persons during a 45 minute collecting effort. In 2015, most E. vermiculata were found scattered among the short vegetation. Several individuals had formed an epiphragma, which may suggest that they were going into hibernation. These finds constitute the first evidence of a persistent E. vermiculata population in Belgium.

Considering the close vicinity of the Zeebrugge harbour, container traffic is the most likely pathway of introduction. Container shipments are known to be an important means by which land molluscs can colonize areas outside their native range. Snails may attach to the exterior of containers or may unintentionally be transported along with ornamental plants or vegetables [10]. In The Netherlands, living E. vermiculata have been found on cauliflower imported from Italy [11]. Eobania vermiculata is also traded and transported for human consumption [12].

There had been doubts about the species' ability to survive the winters in a temperate climate [4], although a population in The Netherlands has 
persisted for at least five years [13]. The low effort required to collect large quantities of living adult and juvenile $E$. vermiculata at Zeebrugge one year after the population was first discovered shows that the species is most probably capable of surviving the Belgian winters. Several other Mediterranean land molluscs proved to be ecologically flexible and have established persistent populations in Belgium, including Lehmannia valentiana [14] and more recently Hygromia cinctella [15].

Eobania vermiculata is considered a potentially invasive species [16]. The early detection of $E$. vermiculata in Belgium allows close monitoring of the small, introduced population and measures to be taken to prevent further spread. Eradication of potentially invasive species is considered the most effective measure in the early stages of invasion, when populations are small and localized [17]. Therefore, in 2015, all E. vermiculata collected at Zeebrugge were removed and euthanized. Additional eradication efforts will be carried out in the near future.

\section{ACKNOWLEDGEMENTS}

The reviewers are thanked for improving the paper. Kirsten Janssens, Franky Bauwens, Dominique Verbeke, Nathal Severijns, Ward Langeraert, Alfred Anthierens, Hans De Blauwe, Emmanuel Dumoulin, Wouter Van Gompel, Ward Vercruysse, Sam Provoost assisted with the fieldwork, which was part of a 'Slak-In-Du project' excursion, aimed at inventorying the molluscan fauna of the coastal region.

\section{REFERENCES}

[1] Welter-Schultes F (2012). European non-marine molluscs, a guide for species identification. Planet Poster Editions, Göttingen. $679 \mathrm{pp}$.

[2] KERNEY MP \& CAMERON RAD (1979). A field guide to the land snails of Britain and North-West Europe. Collins, London, United Kingdom. 288 pp.
[3] Puizina J, Fredotović Ž, ŠAmanić I, ŠUŠnJara T, KeKEZ L, CuKrov D \& PlesLiĆ G (2013). Phylogeography of the land snail Eobania vermiculata (O.F. Müller, 1774) (Gastropoda: Pulmonata) along the Croatian coast and islands. Journal of Entomology and Zoology Studies, 1(4): 23-31.

[4] Soes DM (2014). Een vondst van Eobania vermiculata in Wageningen. Spirula, 398: 8485.

[5] Ueshima R, OKamoto M \& SAito Y (2004). Eobania vermiculata, a land snail newly introduced into Japan. Chirobotan, 35(3): 7174.

[6] HERBERT DG (2010). The introduced terrestrial Mollusca of South Africa. SANBI Biodiversity Series 15. South African National Biodiversity Institute, Pretoria. 108 pp.

[7] Roll U, Dayan T, Simberloff D \& Mienis HK (2009). Non-indigenous land and freshwater gastropods in Israel. Biological Invasions, 11: 1963-1972.

[8] Petney TN \& Huset HC (1992). A species and distribution list of landsnails of Jordan. Argamon, Israel Journal of Malacology, 10: $1-14$.

[9] MIENIS HK (2002). Eobania vermiculata in Iran. Triton, 6: 27.

[10] RoBINSON DG (1999). Alien invasions: the effects of the global economy on non-marine gastropod introductions into the United States. Malacologia, 41(2): 413-438.

[11] BACKHUYS W (1966). Eobania in bloemkool. Correspondentieblad van de Nederlandse Malacologische Vereniging, 120: 1278.

[12] LAZARIDOU-Dimitriadou M \& KatTOULAS M (1981). Contribution a l'étude de la biologie et de la croissance des escargots commercialisés en Grèce: Eobania vermiculata (Müller) et Helix aspersa Müller. Haliotis, 11: 129-137.

[13] MIENIS HK (2015). Nogmaals Eobania vermiculata in Purmerend. Spirula, 402: 15.

[14] Van Loen H, Jordaens K \& Backeljau T (2006). Gedocumenteerde Rode Lijst en naamlijst van de landslakken van Vlaanderen en Brussel. IN/JPM/97002. 248 pp.

[15] VAN DEN Neucker T \& Scheers K (2014). The recent colonisation and rapid spread in Belgium of the alien girdled snail Hygromia 
cinctella (Gastropoda: Hygromiidae). Journal of Conchology, 41(6): 1-2.

[16] Cowie RH, Dillon RT, Robinson DG \& SMITH JW (2009). Alien non-marine snails and slugs of priority quarantine importance in the United States: A preliminary risk assessment. American Malacological Bulletin, 27: 113-132.

[17] EUROPEAN ENVIRONMENT AGENCY (2010). Towards an early warning and information system for invasive alien species (IAS) threatening biodiversity in Europe. 52 pp.

Received: October 18th, 2015

Accepted: January 8th, 2016

Branch editor: Kurt Jordaens 